\title{
VOLUMETRIC \& TRANSPORT BEHAVIOR OF NEUTRAL AMINO ACIDS IN DIFFERENT CONCENTRATIONS OF AN ELECTROLYTE AT $25^{\circ} \mathrm{C}$
}

\author{
Vaneet Dhir $^{1 *}$ and, R. P. Singh Grewal ${ }^{2}$ \\ $1 *$ Post Graduate Department of Chemistry, G.H.G Khalsa College, Gurusar Sadhar (Research Scholar, \\ Punjab Technical University, Jalandhar). \\ ${ }_{2}^{2}$ (Professor, Guru Nanak Dev Engineering College (GNDEC), Ludhiana.
}

*Corresponding Author: -

\begin{abstract}
: -
Apparent molar volumes, $V_{2}$, $\phi$ of glycine, $D L$ - $\alpha$-alanine, $D L$ - $\alpha$-amino-n-butyric acid, $L$-valine and $L$-leucine in water and in $(0.25,0.5,0.75,1.0,1.5,2.0) \mathrm{mol} \cdot \mathrm{kg}^{-1}$ aqueous potassium nitrate solutions have been determined at $T=298.15 \mathrm{~K}$ from density measurements. The standard partial molar volumes at infinite dilution, $V_{2}{ }^{0}$ obtained from $V_{2}$, , have been used to calculate the corresponding volumes of transfer, $\Delta_{t} V^{0}$ from water to aqueous potassium nitrate solutions. The hydration number, $n_{H}$, side chain contributions and volumetric interaction coefficients of these amino acids have also been calculated. The $\Delta_{t} V^{0}$ values for the studied amino acids are positive, and these values increase with an increase in the concentration of $\mathrm{NaNO}_{3}$.
\end{abstract}

Index terms: - Amino acids; Sodium nitrate; Partial molar volumes. 


\section{INTRODUCTION}

The interactions of water with the various functional groups of proteins play crucial role in determining the conformational stability of proteins (Chalikian et al.,1994, Murphy et al. 1998 \& Sorenson et al., 1999). Due to the complex conformational and configurational threedimensional structures of proteins direct investigations of the solute / solvent effect on these biological macromolecules are very challenging. However the amino acids, peptides and their derivatives which are building blocks of proteins and mimic some aspects of proteins have been extensively used to characterize the detailed interactions of the atomic groups that comprise proteins. Thus, in order to gets an idea about the role of hydration in protein folding / unfolding, it is necessary to study both the native and denatured states of a protein. Therefore the physicochemical properties of amino acids and peptides in aqueous solutions remain a subject of extensive investigations (Zhao, 2006).

Salt solutions greatly influence the structure and properties of proteins including their solubility, denaturation, dissociation into subunits and the activity of enzymes (Von Hippel et al. 1969, Jencks et al. 1969). Bhat et al. (1987) from volumes and heat capacities of some amino acids and peptides in aqueous $\mathrm{NaCl}$ and $\mathrm{CaCl}_{2}$ solutions have concluded that $\mathrm{CaCl}_{2}$ acts as a strong destabilizer of protein conformation as compared to $\mathrm{NaCl}$ solutions at the same concentration. Wadi et al. $(1990,1992,1997)$ reported the apparent molar volumes, viscosities and adiabatic compressibilities of some amino acids in aqueous $\mathrm{NH}_{4} \mathrm{Cl}, \mathrm{KSCN}$ and $\mathrm{Na}_{2} \mathrm{SO}_{4}$ solutions at different temperatures. Soto et al. (1999) have reported partial molar volumes of glycine in aqueous $\mathrm{NaNO}_{3}$ solutions only at $298.15 \mathrm{~K}$. Therefore, we (Dhir \& Grewal) have undertaken a systematic study on the volumes of some $\alpha$-amino acids in aqueous $\mathrm{KNO}_{3}$ solutions at different temperatures. Consequently, in the present paper, the apparent molar volumes, V2, $\phi$, of glycine, DL- $\alpha$-alanine, DL- $\alpha$-amino- $n$-butyric acid, L-valine and L-leucine in water and in aqueous sodium nitrate solutions $(0.25,0.5,0.75,1.0,1.5,2.0) \mathrm{molkg}^{-1}$ have been determined by measuring the densities using a vibrating-tube digital densimeter at $\mathrm{T}=298.15 \mathrm{~K}$. From these data, the partial molar volumes at infinite dilution, $V_{2}{ }^{0}$, hydration number, $n_{\mathrm{H}}$, side chain contributions of amino acids, expansibilities and interaction coefficients have been obtained. These parameters have been rationalized in terms of various interactions occurring in these solutions. The concentration effect of sodium nitrate on these parameters has also been discussed.

\section{EXPERIMENTAL SECTION}

Glycine (G-7126, $99 \%$ ), DL- $\alpha$-alanine (A-7502, $99 \%$ ), DL- $\alpha$-amino- $n$-butyric acid (A-1754, $98 \%$ ), Lvaline (V-0500, $99 \%$ ), L-leucine (L-8000, 98 \%) from Sigma Chemical Co. and sodium nitrate (AR, Thomas Baker, India), were used without further purification, however these were dried over anhydrous $\mathrm{CaCl}_{2}$ in a vacuum desiccator before use. Deionized, doubly distilled degassed water with a specific conductance less than $1.3 \times 10^{-6} \Omega^{1} \cdot \mathrm{cm}^{-1}$ was used for the measurements. All solutions were prepared by mass using a Mettler balance with an accuracy of $\pm 0.01 \mathrm{mg}$. The solution densities were measured using a vibrating-tube digital densimeter (model DMA 60/602, Anton paar), having a precision of $\pm 1 \times 10-3 \mathrm{~kg} \cdot$ and an accuracy of $\pm 3 \times 10-3 \mathrm{~kg} \cdot \mathrm{m}-3$.

The temperature of water around the densimeter cell was controlled within $\pm 0.01 \mathrm{~K}$. The densimeter was calibrated by using pure water and dry air. All the density measurements were made with reference to pure water. Working of the densimeter was checked by measuring the densities of aqueous sodium chloride solutions, which agreed well with the literature values (Archer, 1992).

\section{Results and discussion}

The densities, $\rho$, and apparent molar

volumes, $V_{2}$, $\phi$, of amino acids in water and in aqueous sodium nitrate solutions of various molalities ( $m_{\mathrm{s}}$, molality of sodium nitrate solutions, $\mathrm{molkg}^{-1}$ ) at $\mathrm{T}=318.15 \mathrm{~K}$ are given in table 1 . Apparent molar volumes of amino acids have been calculated as follows:

$$
\mathrm{V} 2, \phi=\mathrm{M} / \rho-[(\rho-\rho 0) / \mathrm{m} \cdot \rho \cdot \rho 0],
$$

where $M$ is the molar mass of the amino acid, $m\left(\mathrm{molkg}^{-1}\right)$ is the molality of amino acid, and $\rho$ and $o$ are the densities of solution and solvent

(water or water + sodium nitrate), respectively. The values of uncertainty in apparent molar volumes arising from various experimental measured quantities are of the order of $0.083 \times 10^{-6}$ and $0.035 \times 10^{-6}$ at low and high concentrations respectively of amino acids studied. At infinite dilution, the apparent molar volumes, $V_{2}{ }^{0}$, and partial molar volumes, $V_{2}{ }^{0}$ are

identical $\left(V_{2}{ }^{0},=V_{2}{ }^{0}\right)$. In the case of negligible concentration dependence of $V_{2}, V_{2}{ }^{0}$ was determined by taking the average of all the data points. However, where finite concentration dependence was observed, $V_{2}{ }^{0}$ was determined by least-squares fitting of the data using the following equation.

$$
V_{2, \phi}=V_{2}^{0}+S_{v} m
$$

Where Svis the experimental slope. The experimental values of V20 for the amino acids in water agreed well with those reported in the literature (Wadi et al., 1992, Soto et al., 1999, Bhat et al., 1985, Kharakhoz 1989, Millero et al., 1974, Hakin et al., 1995 \& Hepler 1976).

The standard partial molar volumes of transfer, $\Delta \mathrm{tV} 0$, at infinite dilution from water to aqueous potassiumnitrate solutions have been evaluated as follows:

$\Delta \mathrm{tV} 0=\mathrm{V} 20$ (in aqueous potassium nitrate) $-\mathrm{V} 20$ (in water) 
The $\Delta \mathrm{tV} 0$ values for the amino acids are illustrated in figure 1 . The $\Delta \mathrm{tV0values}$ for the studied amino acids are positive and increase with the increase in concentration of aqueous KNO3solutions.Therefore from the above observed effects of salts on the partial molar volumes of amino acids, it may be concluded that the salts effect the V20values according to Hofmeister series when hydrophobic effect is more (as in case of L-va line and L-leucine) whereas it is not when hydrophilic effect is more (as in case of glycine, DL- $\alpha$-alanine and DL- $\alpha$-aminon-butyric acid). This is also an indication about the importance of the role of hydrophobic effect in the stability of proteins, although more studies are needed for strengthening this point.

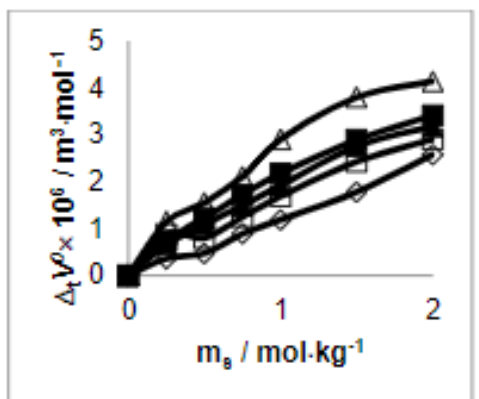

Figure 1. Standard partial molar volumes of transfer, $\Delta \mathrm{t} V 0$, of some amino acids vs. different molalities, ms, of potassiumnitrate solutions: $\Delta$, glycine; $\mathbf{\square}$, DL- $\alpha$ - alanine; $\boldsymbol{\Delta}$, DL- $\alpha$-amino-n-butyric acid; $\square$, L-valine; $\diamond$, L-leucine at T $=298.15 \mathrm{~K}$.

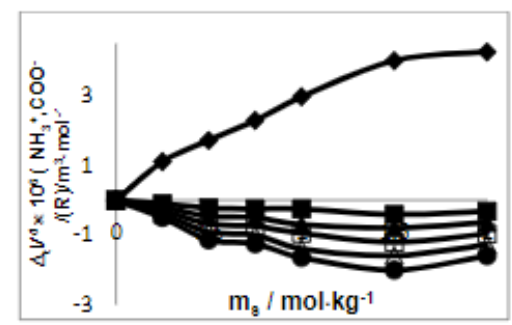

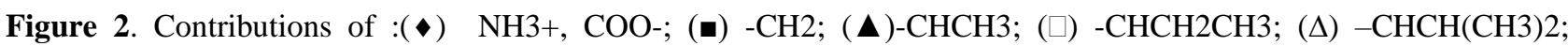
$(\bullet) \mathrm{CHCH} 2 \mathrm{CH}(\mathrm{CH} 3) 2$ groups to standard partial molar volumes of transfer, $\Delta \mathrm{t}$ V0vs. different molalities, msof potassium nitrate solutions at $\mathrm{T}=298.15 \mathrm{~K}$.

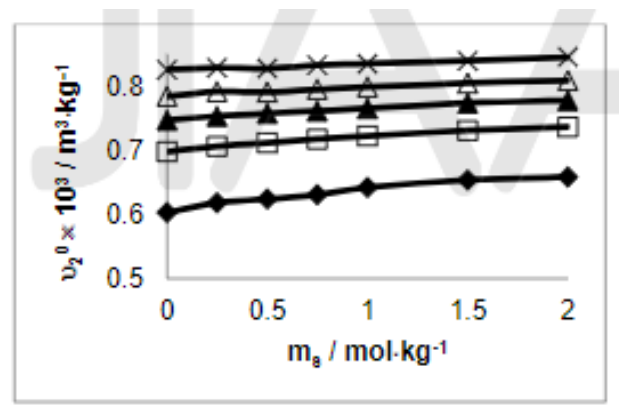

Figure 3. Partial specific volumes, v20, of amino acids vs. different molalities, ms, of potassiumnitrate solutions: ( $\bullet$ ), glycine; $(\square)$, DL- $\alpha$-alanine; $(\boldsymbol{\Delta})$, DL- $\alpha$-amino-n-butyric acid; $(\Delta)$, L-valine; (×), L-leucine at (a) $288.15 \mathrm{~K}$; (b) $298.15 \mathrm{~K}$; (c) $308.15 \mathrm{~K}$; (d) $318.15 \mathrm{k}$.

\section{ACKNOWLEDGMENT}

Vaneet Dhir is very thankful to University Grants Commissions, India for sanctioned research project.

And Punjab Technical University, Kapurthala RoadJalandhar for providing necessary Research facility.

\section{REFERENCES}

[1].Chalikian T.V., Sarvazyan A.P., Breslauer K.J. Biophys. Chem. 51 (1994) 89-109.

[2].Murphy L.R., Matubayasi N., Payne V.A, Levy R.M. Folding Des. 3 (1998) 105118.

[3].Sorenson J.M., Hura G., Soper A.K., Pertsemlidis A., Gaordon T. Head J. Phys. Chem. B 103 (1999) 5413-5426.

[4].Jencks W.P., Catalysis in Chemistry and Enzymology. McGraw-Hill, New York, 1969, pp. 351.

[5].Von Hippel P.H., Schleich T., Acc. Chem. Res. 2 (1969) 257-265.

[6].Bhat R., Ahluwalia J.C., Int. J. Peptide Protein Res. 30 (1987) 145-152.

[7].Wadi R.K., Goyal R.K., J. Chem. Eng. Data. 37 (1992) 377-386.

[8].Wadi R.K., Goyal R.K., J. Solution Chem. 21 (1992) 163-170.

[9].Wadi R.K., Ramasami P., J. Chem. Soc. Faraday Trans. 93 (1997) (2) 243-247.

[10]. Natarajan M., Wadi R.K., Gaur H. C., J. Chem. Eng. Data 35 (1990) 87-93. 
[11]. Soto A., Arce A., Khoshkbarchi M. K., Biophys. Chem. 76 (1999) 73-82.

[12]. Archer D. G., J. Phys. Chem. Ref. Data 21 (1992) 793-829.

[13]. Bhat R., Ahluwalia J. C., J. Phys. Chem. 89 (1985) 1099-1105.

[14]. Kharakoz D. P., Biophys. Chem. 34 (1989) 115-125.

[15]. Millero F. J., Ward G. K., Lepple F. K., Hoff E. V., J. Phys. Chem. 78 (1974) 1636-1643.

[16]. Hakin A.W., Duke M. M., Groft L. L., Marty J. L., Rushfeldt M. L., Can. J. Chem. 73 (1995) 725-734.

[17]. Hepler L. G., Can. J. Chem. 47 (1976) 359-367.

[18]. Gurney R.W., Ionic Processes in Solution, Vol. 3, McGraw Hill, New York, 1953 (Chapter 1).

[19]. Hofmeister F., Arch. Exp. Pathol. Pharmacol, 24 (1888) 247-260.

[20]. Yan Z., Wang J., Kong W., Lu J., Fluid Phase Equilib. 215 (2004) 143150. 